\title{
EFFECT OF LATERALS DRAIN SPACING AND GROUNDWATER DEPTH ON SOIL WATER RELATIONS AND RICE PRODUCTIVITY IN THE NORTH NILE DELTA
}

\author{
M. Kh. El-Ghannam ${ }^{(1)^{*}}$, R. M. Khalifa ${ }^{(2)}$ and B. B. Mikhael(3) \\ (1) Soils, Water and Environment Research Institute, ARC, Giza, Egypt \\ (2) Soils Dep, Faculty of Agriculture, Damietta, Univ, Egypt \\ (3) Rice Research and Training Center, Field Crop Res Institute, ARC, Giza, Egypt \\ *Corresponding author: Mohamed.elghannam@arc.sci.eg
}

Received: Nov. 24, 2020

Accepted: Dec. 16,2020

\begin{abstract}
A field experiment was conducted in alluvial clay soil located at the north Nile Delta (Motobus District, Kafrelshiekh Governorate, Egypt). The soil was cultivated with rice crop (Oryza sativa $L$.) during two summer seasons 2018 and 2019. The impact of lateral drain spacing at $20 \mathrm{~m}$ and $40 \mathrm{~m}$ between laterals (main plots) with controlled drainage $(C D)$ at $0.4,0.8 \mathrm{~m}$ depth and uncontrolled drainage at $1.2 \mathrm{~m}$ below soil surface (sub plots) was studied to evaluate soil-water properties, Nitrate losses, water saving, rice productivity and economic return under rice crop cultivation.
\end{abstract}

Results showed that the relative groundwater depth values (RGWD) are inversely proportional to the drain spacing treatments. The highest values of drainable porosity $(0.145$ and $0.141 \%)$ were achieved in the plots subjected to $20 \mathrm{~m}$ drain spacing with uncontrolled treatment, while the lowest values ( 0.1 and $0.101 \%$ ) were obtained at $40 \mathrm{~m}$ drain spacing with $0.4 \mathrm{~m}$ controlled drainage in both seasons, respectively.

It's clear that narrow drain spacing of $20 \mathrm{~m}$ and water table depth at $0.4 \mathrm{~m}$ was more efficient than the wider drain spacing at $40 \mathrm{~m}$ in reducing values of soil salinity, SAR and bulk density compared with its values before installation of drainage system. On the other, hand it gave the highest values for water saving, nitrate saving, productivity of irrigation water, rice yields, net return, net income from water unit, economic efficiency compared to wider drain spacing $(40 \mathrm{~m})$ with $1.2 \mathrm{~m}$ ground water depth. The controlled drainage reduced drainage outflow compared to conventional drainage. It can be concluded that the treatment of controlled drainage gave more profit than the uncontrolled one.

Key words: Nitrate losses, drainable porosity, drain spacing, ground water depth, discharge rate, rice crop, economic return.

\section{INTRODUCTION}

Subsurface drainage is widely practiced in the Nile Delta region. Subsurface tile drainage has been effective in draining croplands. Detailed controlled studies were undertaken in order to understand the salt dynamics under rice and associated crops and their impact on soil and drainage water quality. This includes the influence of different crop rotations, farm practices, and subsurface drainage status on salt buildup, and the contribution of groundwater to evapotranspiration (Skaggs et al., 2012; El-Ghannam et al., 2016).

Excessive drainage might result in soil water deficit, nutrient leaching, and low irrigation system- and water use efficiencies (Campus, 2019). Therefore, the role of subsurface drainage might be changed from only controlling waterlogging and/or salinity to an essential element of integrated water and water-table (WT) management (Javani et al., 2018). 
The ultimate objective of water table (WT) management is to maintain it at the desired depth to ensure adequate rootzone aeration (Lavaire et al., 2017). In controlled drainage (CD), the drains are shallower than in the free system, thus WT is maintained at lower depth, as a result, $C D$ reduces deep percolation and increases upward flow by capillary as evapotranspiration reduces soil content in the surface soil layer (Lu et al., 2016). Therefore, the use of CD increase water availability for crops during dry periods thus reduced drought or water deficit (Skaggs et al., 2012). Controlled drainage was capable of reducing drainage volume and nitrate-nitrogen loss by $40 \%$ to $50 \%$ compared to conventional free drainage (Skaggs et al., 2010). Phosphorus losses were decreased by $25 \%$ to $35 \%$. These general findings have been confirmed elsewhere (Feser et al.,2010), resulting in the generalization that a properly sited and managed controlled drainage system can lower discharges and pollutant loads by roughly $30 \%$ compared to free drainage systems. The benefit of controlled drainage on crop yields has generally been modest and highly dependent on management and soil conditions. Several studies suggest that crop yields from controlled drainage systems may surpass those from conventional or free drainage systems by $5 \%$ to $10 \%$ (Skaggs et al., 2012 and Sobeih et al., 2017).

The outflow from the $6 \mathrm{~m}$ spacing treatment was approximately 2 times that of the $12 \mathrm{~m}$ spacing treatment for all levels of outflow. Water table heights mid-way between adjacent drain lines averaged 100 $\mathrm{mm}$ lower on the $3 \mathrm{~m}$ spacing plots compared to the 6 and $12 \mathrm{~m}$ spacing plots for periods when the water table for all treatments was above the compacted subsoil. The sum of the excess water table levels above a $\mathbf{3 0 0} \mathrm{mm}$ depth for the $3 \mathrm{~m}$ spacing treatment were significantly lower than those for the 6 and12 $\mathrm{m}$ spacing treatments (Madani and Brenton
1994). The subsurface drainage with spacing of $15 \mathrm{~m}$ and depth of $80 \mathrm{~cm}$ (due to the proper water table depth and higher yield) and subsurface drainage with distance of $10 \mathrm{~m}$ and depth of $80 \mathrm{~cm}$ (due to the highest resistance to penetrometer penetration and the lowest soil moisture content) are recommended as the best drainage treatment for midseason and end-season drainage, respectively (Alizadeh et al 2018).

The reductions in the drained water volumes corresponded an increase in evapotranspiration and plant water uptake (Craft et al., 2018) and reduce $\mathrm{N}$ transport (by $18 \%$ to $75 \%$ ) and total P (by $35 \%-45 \%$ ) depending on drainage system design, climate, soil, and site conditions (Ayars et al., 2006; Craft et al., 2018; Drury et al., 2009; Helmers et al., 2012; Javani et al., 2018; Lavaire et al., 2017; Liu et al., 2019; Lu et al., 2016; Skaggs et al., 2012).

Rice (Oryza sativa L.) is the staple food for more than half of the human population, and as such it plays a key role in ensuring food security all over the world. Rice crop plays a significant role in Egypt, for sustaining the food selfsufficiency and for export. Rice is considered the most popular and important field crop in Egypt for several reasons: as a staple food for more than $50 \%$ of Egyptians, as an important exporting crop, as a land reclamation crop for improving the productivity of the saline soils widely spread in Nile Delta and coastal area (IRRI,2020). Average rice yield obtained under subsurface drainage systems were however noticeably higher when compared with harvest from fields without such a drainage facility irrespective of the season (Elghannam et al., 2016).

The main objective of the current work was to study the effect of drainage dynamics on rice productivity, with respect to compute irrigation water Also, to find out the proper depth of water table 
in computing irrigation water in North Nile Delta region where the study took place and to find out the most suitable lateral distance for maximizing cropwater productivity.

\section{MATERIALS AND METHODS}

A field experiment was conducted during the two summer seasons (2018 and 2019), to determine the impact of drain spacing at $20 \mathrm{~m}$ and $40 \mathrm{~m}$ between laterals (main plots) with controlled drainage at $40 \mathrm{~cm}, 80 \mathrm{~cm}$ and $(120 \mathrm{~cm}$ un managed treatment) below soil surface (sub plots) on soil salinity, water saving, nitrate losses, productivity and economic returns for water and yield of rice crop.

The experiment is located at $31^{\circ} 21$ 33.77 Latitude and $31^{\circ} 38^{\prime}$ ' $47.7^{\prime \prime}$ Longitude in Motobus District, Kafr El-Sheikh Governorate, Egypt. The tile lines were spaced to simulate a $20 \mathrm{~m}$ and $40 \mathrm{~m}$ spacing, $100 \mathrm{~m}$ length and $1.2 \mathrm{~m}$ depth with a slope of $0.1 \%$. Some soil properties before conducting the experiments are presented in Table (1). The different agricultural practices were performed as recommended through the two growing seasons. In the summer seasons (2018 and 2019) rice (Oryza sativa) Sakha Super 300 cultivar was transplanted in $15^{\text {th }}$ June, 2018 and $25^{\text {th }}$ May, 2019. All plots received $150 \mathrm{~kg}$ fed. ${ }^{-1}$ Ca-superphosphate $\left(15.5 \% \mathrm{P}_{2} \mathrm{O}_{5}\right)$ during tillage operation and nitrogen was applied at rate of $100 \mathrm{~kg}$ fed. $^{-1}$ (as urea $46.5 \% \mathrm{~N}$ ) in one dose after 15 days from transplanting. Rice was harvested on the $25^{\text {th }}$ of September, 2018 and $15^{\text {th }}$ of September, 2019. Grains and straw yields of rice were determined and converting to $\mathrm{kg} \mathrm{fed}^{-1}$ for different treatments.

Soil samples were taken to a depth of $1.2 \mathrm{~m}$, before conducting the experiment and after harvesting the first and second seasons for analysis. Salinity was determined in saturated soil paste extract according to Page et al., (1982). Soil bulk density and total porosity of the soil were measured using the core sampling technique as described by Campbell (1994). Drain discharge rates were manually measured two times every day when drain flow occurred, by measuring the amount of water running from tile line during a short interval and converting to $\mathrm{m}^{3} \mathrm{fed}^{-1}$. The average daily discharge rates were used in this study as recommended by Dieleman and Trafford, 1976. Several water samples from tile effluent (as drainage water) were collected at different times along the day and composite daily samples were taken for analysis. The water samples taken from tiles were analyzed for $\mathrm{NO}_{3}^{-}$using Kjeldahl method and available $\mathrm{N}$ content of soil were determined using Kjeldahl digestion (Cottenie et al., 1982).

Table (1): The initial of some soil properties for the experimental field

\begin{tabular}{|c|c|c|c|c|c|c|c|c|c|c|}
\hline \multirow{2}{*}{$\begin{array}{c}\text { Soil } \\
\text { depth } \\
\text { (cm) }\end{array}$} & \multicolumn{3}{|c|}{$\begin{array}{l}\text { Particle size } \\
\text { distribution\% }\end{array}$} & \multirow{2}{*}{$\begin{array}{l}\text { Texture } \\
\text { grade }\end{array}$} & \multirow{2}{*}{$\begin{array}{c}E C \\
\left(\mathrm{dSm}^{-1}\right)\end{array}$} & \multirow{2}{*}{ SAR } & \multirow{2}{*}{$\begin{array}{c}\text { CEC } \\
\text { Meql } \\
\text { 100g soil }\end{array}$} & \multirow{2}{*}{ pH } & \multirow{2}{*}{$\begin{array}{c}\text { OM } \\
\%\end{array}$} & \multirow{2}{*}{$\begin{array}{c}\text { Available } \\
\mathrm{N}\left(\mathrm{mgkg}^{-1}\right)\end{array}$} \\
\hline & Sand & Silt & Clay & & & & & & & \\
\hline $0-30$ & 16.70 & 33.27 & 50.03 & Clayey & 2.57 & 3.4 & 44.6 & 7.95 & 1.94 & 16.4 \\
\hline $30-60$ & 15.55 & 34.5 & 49.95 & Clayey & 2.85 & 3.9 & 37.6 & 8.10 & 1.80 & 24.5 \\
\hline $60-90$ & 17.52 & 32.54 & 49.94 & Clayey & 3.25 & 4.5 & 36.0 & 8.15 & 1.62 & 19.5 \\
\hline $90-120$ & 20.45 & 30.54 & 49.01 & Clayey & 3.40 & 5.35 & 39.5 & 8.17 & 1.25 & 22.55 \\
\hline Mean & 17.55 & 32.71 & 49.73 & Clayey & 3.02 & 4.29 & 39.42 & & 1.65 & 20.73 \\
\hline
\end{tabular}




\section{Applied irrigation water}

Amount of irrigation water was measured by using a rectangular sharp crested weir. The discharge was calculated using the following equation as described by (Masoud, 1969), as follows

$$
\mathrm{Q}=\mathrm{CL}(\mathrm{H})^{\wedge} 1.5
$$

Where: $\mathrm{Q}=$ Discharge $\left(\mathrm{m}^{3} \mathrm{~s}^{-1}\right), \mathrm{L}=$ Length of the crest $(m), H=$ Head above the weir $(\mathrm{m}), \mathrm{C}=$ Empirical coefficient determined from discharge measurement.

Productivity of irrigation water (PIW, $\mathrm{kgm}^{-3}$ ) was calculated according to Ali et al., (2007) as follows:

$$
\text { PIW = Gy/WA, where }
$$

$G y=$ Grain and straw yields, kg fed. ${ }^{-1}$, WA $=$ Water applied, $\mathrm{m}^{3}$ fed $^{-1}$

\section{Drainable Porosity (f )}

Soil drainable porosity $(f)$ is defined as the volume of water that is drained (or taken up) by a unit volume of soil when the water table drops or rises over a unit distance. The value of $(f)$ is not generally constant but besides other things, it is a function of water table depth i.e. soil depth, Z (Taylor, 1960). The time of drawdown and shape of the water table depends on the particular way in which drainable porosity is related to water table depth. Thus, it is convenient and often necessary in drawdown studies to express $f$ as a function of $Z$. A functional relationship between $f$ and $Z$ was developed by regression which is described by the following equation:

$$
f=a z^{b}
$$

Where ' $a$ ' and ' $b$ ' are the regression coefficients $(a=0.138 ; b=0.550)$.

\section{Salt balance}

Salt residual $\left(\mathrm{kgfed}^{-1}\right)$ was calculated by deducting the salt removed from salt added, $\left(\mathrm{kgfed}^{-1}\right)$. Salt added $\left(\mathrm{kgfed}^{-1}\right)$ was calculated by multiplying irrigation water amount $\left(\mathrm{m}^{3} \mathrm{fed}^{-1}\right)$ by its salinity (EC, $\mathrm{dSm}^{-1}$ ) and 0.64. Salt removed $\left(\mathrm{kgfed}^{-1}\right)$ was calculated by multiplying drainage water amount $\left(\mathrm{m}^{3} \mathrm{fed}^{-1}\right)$ by its salinity $\left(E C, \mathrm{dSm}^{-1}\right)$ and 0.64, whereas; $\mathrm{EC} \times 0.64=$ $\frac{g m}{\text { iter }}=\frac{10^{-3} \mathrm{~kg}}{10^{3}\left(10^{-6} \mathrm{~m}^{3}\right)}=\frac{\mathrm{kg}}{\mathrm{m}^{3}}=\frac{\mathrm{kgfed}^{-1}}{\mathrm{~m}^{3} \mathrm{fed}^{-1}}$

\section{Economic evaluation}

Cash inflows and outflows for various treatments (at prices of the local market) were calculated, and some economic indicators were estimated such as:

- Net return: It can be calculated by deducting the total cost from the total return, (LEfed. - $^{-1}$ )

- Economic efficiency: It can be calculated by dividing the total seasonal net return on total seasonal cost

- Net return from water unit (L.E $\mathrm{m}^{3}$ ): It can be calculated by dividing seasonal net return (LE fed.- ${ }^{-1}$ ) on seasonal water applied $\left(m^{3}\right.$ fed.$\left.^{-1}\right)$.

Meteorological data such as monthly temperature $\left({ }^{\circ} \mathrm{C}\right)$, relative humidity and rainfall of Sakha area, Kafr El-Sheikh Governorate during the two growing summer seasons 2018 and 2019 are shown in Table 2. The data were estimated from Sakha meteorological station in the studied area.

\section{Statistical analysis:}

Data obtained for rice grain and straw yields are subjected to statistical analysis according to Snedecor and Cochran (1980). The differences between the means compared by Dukun's multiple range test. 
Table 2: Monthly maximum and minimum temperature $\left({ }^{\circ} \mathrm{C}\right)$, relative humidity $(\%)$, wind speed and Pan Evaporation at the experimental site during the two growing seasons

\begin{tabular}{|c|c|c|c|c|c|c|c|}
\hline \multirow{2}{*}{ Months } & \multicolumn{3}{|c|}{ Air Temperature $\left({ }^{\circ} \mathrm{C}\right)$} & \multicolumn{2}{|c|}{$\begin{array}{c}\text { Relative } \\
\text { humidity (\%) }\end{array}$} & \multirow{2}{*}{\begin{tabular}{|c}
$\begin{array}{c}\text { Wind } \\
\text { speed }\end{array}$ \\
$\mathrm{Km} \mathrm{day}^{-1}$
\end{tabular}} & \multirow{2}{*}{$\frac{\text { Pan E }}{\mathrm{mm} \mathrm{day}^{-1}}$} \\
\hline & Max & Min & Mean & Max & Min & & \\
\hline \multicolumn{8}{|c|}{$1^{\text {St }}$ season 2018} \\
\hline May & 31.2 & 23.8 & 27.5 & 75.6 & 43.9 & 95.8 & 6.33 \\
\hline June & 32.6 & 25.3 & 29.0 & 75.5 & 48.0 & 98.6 & 7.71 \\
\hline July & 34.2 & 25.4 & 29.8 & 82.6 & 51.0 & 89.5 & 7.37 \\
\hline August & 33.9 & 25.2 & 29.6 & 82.4 & 51.8 & 76.0 & 6.42 \\
\hline September & 32.8 & 23.5 & 28.2 & 83.1 & 48.3 & 68.7 & 4.98 \\
\hline \multicolumn{8}{|c|}{$2^{\text {nd }}$ season 2019} \\
\hline May & 31.9 & 25.4 & 28.7 & 76.4 & 37.9 & 68.4 & 6.83 \\
\hline June & 33.0 & 28.0 & 30.5 & 81.5 & 50.0 & 103.0 & 8.46 \\
\hline July & 33.5 & 28.4 & 31.0 & 85.2 & 54.4 & 83.8 & 8.08 \\
\hline August & 34.2 & 28.9 & 31.6 & 89.7 & 55.6 & 68.7 & 6.82 \\
\hline September & 32.4 & 27.9 & 30.2 & 83.4 & 52.9 & 76.9 & 5.90 \\
\hline
\end{tabular}

\section{RESULTS AND DISCUSSION}

\section{Relative groundwater depth (RGWD)}

The drainage systems are mainly constructed in the arid and semi-arid regions to remove both of excess groundwater and soluble salts. In Egypt, the intended groundwater depth was taken as $0.8 \mathrm{~m}$ indicating that the values more than one-meter reveal to a good drainage conditions and vis versa. Water table depth in the plots which not subjected to subsurface open drains is high and mostly close to the ground surface, so the RGWD values are smaller than that in drained plots. On the other hand, the relative groundwater depth values (RGWD) are inversely proportional to the drain spacing treatments indicating the high efficient of narrow drain spacing to evacuate excess groundwater (Table 3). The high groundwater under the highly evaporation conditions predominated in the studied area rises to ground surface by capillary fringes, evaporates and leaves a considerable amounts of soluble salts. The increase percentages in relative groundwater depth are $0.67,0.91$ and $1.10 \mathrm{~m}$ in the plots subjected to drain spacing of $20 \mathrm{~m}$ and $0.58,0.79$ and $1.01 \mathrm{~m}$ for $40 \mathrm{~m}$ spacing of drain under 40,80 and $120 \mathrm{~cm}$ of water table, respectively during 2018 growing season. As the same trend in the second growing season, these findings are agreed with those of Gupta et al., (1998) and Abdalla (2000) who stated that the decrease in drain spacing was more efficient to lower groundwater depth resulting in a good aeration and improving soil structure. Such improvements in soil structure play an important role in root and water penetration and consequently enhance the rooting depth of most crops, (Armstrong et al, 1990). 
Table (3): Effect of controlled drainage and drain spacing treatments on relative groundwater depth (RGWD), physical and chemical properties among two summer seasons of 2018 and2019

\begin{tabular}{|c|c|c|c|c|c|c|c|}
\hline \multicolumn{2}{|c|}{ Treatments } & \multirow[b]{2}{*}{ RGWD } & \multirow[b]{2}{*}{$\begin{array}{c}\text { Bulk } \\
\text { density } \\
\mathrm{Mg} / \mathrm{m}^{3}\end{array}$} & \multirow{2}{*}{$\begin{array}{c}\text { Total } \\
\text { porosity } \\
\%\end{array}$} & \multirow[b]{2}{*}{$\begin{array}{c}\text { Drainable } \\
\text { porosity } \\
\%\end{array}$} & \multirow[b]{2}{*}{$\begin{array}{c}\text { EC of GW } \\
\mathrm{dSm}^{-1}\end{array}$} & \multirow[b]{2}{*}{ SAR } \\
\hline $\begin{array}{c}\text { Drain } \\
\text { space } \\
\text { (m) }\end{array}$ & $\begin{array}{c}\text { Drain } \\
\text { depth } \\
\text { (m) }\end{array}$ & & & & & & \\
\hline \multicolumn{8}{|c|}{$1^{\text {st }}$ season 2018} \\
\hline \multirow{3}{*}{20} & 0.4 & 0.67 & 1.27 & 52.07 & 0.11 & 2.35 & 5.40 \\
\hline & 0.8 & 0.91 & 1.29 & 51.32 & 0.13 & 2.15 & 4.70 \\
\hline & 1.20 & 1.10 & 1.30 & 50.94 & 0.145 & 1.75 & 3.55 \\
\hline \multirow{3}{*}{40} & 0.4 & 0.58 & 1.29 & 51.31 & 0.10 & 2.85 & 6.70 \\
\hline & 0.8 & 0.79 & 1.32 & 50.18 & 0.117 & 2.45 & 5.85 \\
\hline & 1.20 & 1.01 & 1.35 & 49.05 & 0.138 & 2.1 & 4.50 \\
\hline \multicolumn{8}{|c|}{$2^{\text {nd }}$ season 2019} \\
\hline \multirow{3}{*}{20} & 0.4 & 0.63 & 1.28 & 51.69 & 0.107 & 2.45 & 5.25 \\
\hline & 0.8 & 0.89 & 1.28 & 51.69 & 0.129 & 2.29 & 4.65 \\
\hline & 1.20 & 1.05 & 1.30 & 50.94 & 0.141 & 1.62 & 2.25 \\
\hline \multirow{3}{*}{40} & 0.4 & 0.57 & 1.27 & 52.07 & 0.101 & 2.55 & 6.75 \\
\hline & 0.8 & 0.75 & 1.31 & 50.56 & 0.118 & 2.19 & 4.90 \\
\hline & 1.20 & 0.99 & 1.32 & 50.18 & 0.137 & 1.16 & 2.45 \\
\hline
\end{tabular}

\section{Drainable porosity (f)}

Drainable porosity outlined the effectiveness of drainage to improve soil structure. Good structure means favorable conditions for simultaneous aeration and storage of soil moisture. The highest values (0.145 and $0.141 \%)$ with $1.2 \mathrm{~m}$ of ground water table (unmanaged treatment) as well as $20 \mathrm{~m}$ drain spacing and lowest one of drainable porosity $(0.1$ and $0.101 \%)$ are achieved in the plots subjected to $40 \mathrm{~m}$ drain spacing treatment and controlled drainage at $40 \mathrm{~cm}$ depth of water table in the both seasons respectively, (Table 3). On the other hand, the effect of drainage installation age is clearly pronounced on the drainable porosity, where the greatest values of (f) are achieved after two years of drain installation. This favorable effect may be due to the friable granules existing after drainage installation, which promotes wetting and drying cycles sufficient to bring about cracking and aeration of the soil.

\section{Soil salinity}

Implementation of strategies aimed to increase plant water use from a shallow groundwater source since it will need to carefully consider soil salinity increases and implement appropriate monitoring. While the increase in soil salinity is a drawback associated with controlled drainage, mitigation of its effects should be possible by leaching between periods of controlled drainage, e.g. allowing free drainage during the first irrigation of the next season.

Results concerning the soil salinity of the studied soil before and after the two growing seasons are given in Table (4). It is clear from the obtained data that, salinity (ECe) of the soil before the experimental setup was moderate and varied from 2.57 to $3.4 \mathrm{dSm}^{-1}$ with an average of $3.02 \mathrm{dSm}^{-1}$ for all depths during the $1^{\text {st }}$ growing season and varied from 2.4 to $3.9 \mathrm{dSm}^{-1}$ with an average $3.16 \mathrm{dSm}^{-1}$ in the $2^{\text {nd }}$ season. 
Table (4): Effect of distance and depth of lateral treatments on salinity (EC), $\mathrm{dSm}^{-1}$ distribution in the studied soils

\begin{tabular}{|l|c|c|c|c|c|c|c|}
\hline \multirow{2}{*}{$\begin{array}{l}\text { Soil depth } \\
\text { (cm) }\end{array}$} & \multirow{2}{*}{$\begin{array}{l}\text { Initial } \\
\text { dSm }\end{array}$} & \multicolumn{7}{|c|}{$\begin{array}{c}40 \mathrm{~cm} \\
\text { depth }\end{array}$} & $\begin{array}{c}80 \mathrm{~cm} \\
\text { depth }\end{array}$ & $\begin{array}{c}120 \mathrm{~cm} \\
\text { depth }\end{array}$ & $\begin{array}{c}40 \mathrm{~cm} \\
\text { depth }\end{array}$ & $\begin{array}{c}80 \mathrm{~cm} \\
\text { depth }\end{array}$ & $\begin{array}{c}120 \mathrm{~cm} \\
\text { depth }\end{array}$ \\
\hline \multicolumn{7}{|c|}{ season 2018} \\
\hline $0-30$ & 2.57 & 1.75 & 1.50 & 1.40 & 1.95 & 1.90 & 1.50 \\
\hline $30-60$ & 2.85 & 2.10 & 1.90 & 1.70 & 2.91 & 2.15 & 1.80 \\
\hline $60-90$ & 3.25 & 2.90 & 2.10 & 1.90 & 3.35 & 2.50 & 2.10 \\
\hline $90-120$ & 3.40 & 3.25 & 3.10 & 2.25 & 3.95 & 3.70 & 2.70 \\
\hline Average & 3.02 & 2.50 & 2.15 & 1.81 & 3.04 & 2.56 & 2.03 \\
\hline \multicolumn{7}{|c|}{$2^{\text {nd }}$ season 2019} \\
\hline $0-30$ & 2.40 & 1.85 & 2.35 & 1.40 & 2.30 & 2.50 & 1.70 \\
\hline $30-60$ & 2.90 & 2.10 & 2.70 & 1.90 & 2.50 & 2.85 & 2.15 \\
\hline $60-90$ & 3.45 & 2.75 & 3.17 & 2.70 & 3.10 & 3.30 & 2.95 \\
\hline $90-120$ & 3.90 & 3.15 & 3.10 & 3.40 & 3.50 & 3.50 & 3.65 \\
\hline Average & 3.16 & 2.46 & 2.83 & 2.35 & 2.85 & 3.04 & 2.61 \\
\hline
\end{tabular}

Results in Table (4) show that, the salinity of the soil after rice harvesting were 2.5, 2.15 and $1.81 \mathrm{dSm}^{-1}$ for 40,80 and $120 \mathrm{~cm}$ of water table depth under 20 $\mathrm{m}$ spacing between laterals, while the corresponding values were $3.04,2.56$ and $2.03 \mathrm{dSm}^{-1}$ for 40,80 and $120 \mathrm{~cm}$ depth of water table under $40 \mathrm{~m}$ spacing lateral after the first growing season. On the second season the soil salinity values 2.46, 2.83 and $2.35 \mathrm{dSm}^{-1}$ for managed treatments $40,80 \mathrm{~cm}$ depth of water table as well as un managed $120 \mathrm{~cm}$ depth of ground water under $20 \mathrm{~m}$ spacing, while the salinity values were $2.85,3.04$ and $2.61 \mathrm{dSm}^{-1}$ for 40 and 80 $\mathrm{cm}$ controlled drainage and uncontrolled treatment $(120 \mathrm{~cm})$ respectively. These results indicate that the applied treatments caused decrease of soil salinity compared to free drainage treatment before installation of drainage system. The effect of drainage intensity and rice crop on reducing soil salinity is attributed to the increase of leaching salts with drainage water. Similar results were obtained by (Hornbuckle, 2003).

It is obvious that secondary salinization due to the capillary rise of groundwater table is the main source of soil salinity in the studied soils. In general salt concentration and its composition reflect the balance between the different sources of recharge and discharge and the interaction between water table and soil salinity.

\section{Drain discharge}

Data in Table (5) showed that the mean values of lateral drain discharge as affected by controlled drainage treatments under rice crop during the two successive seasons of 2018 and 2019. Concerning to the treatments of 40 and $80 \mathrm{~cm}$ the disposal of drains discharge started during irrigation and increased to the high value after few hours from irrigation then decreased with time for all irrigation cycles. Ibrahim et al., 2002. Antar, 2007 and Ramadan et al., 2009 
pointed out that the majority of water discharge in clay soil is from preferential flow or from water movement through soil cracks and macro pores.

It's worth to mention that, the cumulative drain discharge $\left(\mathrm{m}^{3} \mathrm{fed}^{-1}\right)$ was higher under uncontrolled treatment of $120 \mathrm{~cm}$ than $40 \mathrm{~cm}$. The values of total cumulative drain discharge were 927 and $1651.3 \mathrm{~m}^{3} \mathrm{fed}^{-1}$ under $20 \mathrm{~m}$ spacing of lateral and 855 and $1467.5 \mathrm{~m}^{3}$ fed $^{-1}$ for 40 $\mathrm{m}$ spacing for water table levels of 40 and $120 \mathrm{~cm}$, respectively in the first season. While in the second season the data were 932.4 and $1676.5 \mathrm{~m}^{3}$ fed $^{-1}$ under $20 \mathrm{~m}$ spacing and 833 and $1551 \mathrm{~m}^{3} \mathrm{fed}^{-1}$ under $40 \mathrm{~m}$ spacing for ground water table depth of 40 and $120 \mathrm{~cm}$, respectively.

It can be seen that, the controlled drainage reduced drainage outflow compared to conventional drainage without outlet control under different spacing of drainage lateral. The different outflow volumes had a large effect on the salt loads; the uncontrolled drainage removed more substantial loss of salts than the controlled drainage treatments. The obtained results are in the accordance with those reported by Evans et al., (1996). After harvesting for each season the control valves were removed from the controlled drainage laterals to allow the drains to flow freely and some salts were leached. This provided the opportunity to compare the performance of those laterals with and without control valves. It can be clearly seen that controlled drainage was effective in controlling drain discharge and this caused a reduction in drainage discharge which had the benefit of reducing disposal problems due to the decreased drainage volumes and subsequently lower salt loads to drains. However, two issues need to be considered regarding the suitability of controlled drainage. Firstly, if controlled drainage management is to be successful then it relies on the crop being able to successfully use water from the water table to meet part of its evapotranspiration requirements, secondly, it can be seen that salt accumulation occurred in the controlled drainage treatments. Therefore, the effects of controlled drainage on soil salinity levels need to be thoroughly investigated in order to assess the sustainability of the system (EIGhannam et al., 2016).

\section{Nitrate in drainage water}

Drainage water management is a conservation practice that has the potential to reduce drainage outflow and nitrate loss from agricultural fields which maintaining or improving crop yields. Data in Table (5) show the nitrate losses as affected by controlled drainage during the two successive seasons of 2018 and 2019 under rice crop. Seasonal concentration of $\mathrm{NO}_{3}{ }^{-} \mathrm{N}$-loss in drainage water varied from 34 to $48 \mathrm{ppm}$ with $20 \mathrm{~m}$ spacing and varied from 31 to $44 \mathrm{ppm}$ under $40 \mathrm{~m}$ spacing for free drainage treatment $(120 \mathrm{~cm}$ depth of water table) and $40 \mathrm{~cm}$ of water table depth treatment in the $1^{\text {st }}$ season. While in the $2^{\text {nd }}$ growing season, the values of $\mathrm{NO}_{3}^{-} \mathrm{N}$ loss in the drainage water fluctuated from 34 to $50 \mathrm{ppm}$ under $20 \mathrm{~m}$ lateral distance and varied from 39 to $53 \mathrm{ppm}$ through $\mathbf{4 0}$ $\mathrm{m}$ lateral spacing for the free drainage compared to controlled drainage at $40 \mathrm{~cm}$ depth of water table.

The cumulative nitrate loss in the subsurface drainage water from the free drainage treatment $(56.14$ and 45.49 $\mathrm{kgfed}^{-1}$ for 20 and $40 \mathrm{~m}$ lateral spacing, respectively) were greater than the controlled drainage at $40 \mathrm{~cm}$ depth of water table (44.5 and $37.62 \mathrm{~kg} \mathrm{fed}^{-1}$ for 20 and $40 \mathrm{~m}$ lateral spacing, respectively) by 20.74 and $17.31 \%$ in the first season. 
Table (5): Effect of distance and depth of lateral treatments on drain outflow and Nitrate losses.

\begin{tabular}{|c|c|c|c|c|c|}
\hline \multicolumn{2}{|c|}{ Treatments } & \multirow{2}{*}{$\begin{array}{c}\text { Drains } \\
\text { discharge } \\
\left(\mathrm{m}^{3} \mathrm{fed}^{-1}\right)\end{array}$} & \multirow[b]{2}{*}{$\begin{array}{l}\mathrm{NO}_{3}-\mathrm{Con}, \\
(\mathrm{ppm})\end{array}$} & \multirow{2}{*}{$\begin{array}{c}\text { Losses } \mathrm{NO}_{3} \\
\left(\text { kgfed }^{-1}\right)\end{array}$} & \multirow{2}{*}{$\begin{array}{c}\text { Saving } \mathrm{NO}_{3}^{-} \\
(\%)\end{array}$} \\
\hline $\begin{array}{c}\text { Drains } \\
\text { distance }(m)\end{array}$ & $\begin{array}{l}\text { Ground water } \\
\text { depth (cm) }\end{array}$ & & & & \\
\hline \multicolumn{6}{|c|}{$1^{\text {st }}$ season } \\
\hline \multirow{3}{*}{20} & 40 & 927.0 & 48 & 44.50 & 20.74 \\
\hline & 80 & 1110.0 & 43 & 47.73 & 14.98 \\
\hline & 120 & 1651.3 & 34 & 56.14 & - \\
\hline \multirow{3}{*}{40} & 40 & 855.0 & 44 & 37.62 & 17.31 \\
\hline & 80 & 1043.0 & 38 & 39.63 & 12.88 \\
\hline & 120 & 1467.5 & 31 & 45.49 & - \\
\hline \multicolumn{6}{|c|}{$2^{\text {nd }}$ season } \\
\hline \multirow{3}{*}{20} & 40 & 932.4 & 50 & 46.62 & 18.21 \\
\hline & 80 & 1145.0 & 44 & 50.38 & 11.62 \\
\hline & 120 & 1676.5 & 34 & 57.00 & - \\
\hline \multirow{3}{*}{40} & 40 & 833.0 & 53 & 44.15 & 27.01 \\
\hline & 80 & 1103.0 & 45 & 49.64 & 17.94 \\
\hline & 120 & 1551.0 & 39 & 60.49 & - \\
\hline
\end{tabular}

The seasonal nitrate loss was reduced from (57 and $\left.60.49 \mathrm{~kg} \mathrm{fed}^{-1}\right)$ for the free drainage to $\left(46.62\right.$ and $\left.44.15 \mathrm{~kg} \mathrm{fed}^{-1}\right)$ for the $40 \mathrm{~cm}$ depth of water table treatment in the $2^{\text {nd }}$ season for 20 and $\mathbf{4 0} \mathrm{m}$ lateral spacing, respectively. It can be concluded that, the volume of water that flowed through the soil was a primary factor responsible for $\mathrm{N}$ loss. These findings are in accordance of that reported by Tan et al., (1993) and Drury et al., (1996).

The amount of nitrate had been saved to rice crop in 2018 season under different treatments were 20.74, and $14.98 \%$, for the 40 and $80 \mathrm{~cm}$ water table depths under $20 \mathrm{~m}$ spacing and 17.31 and $12.88 \%$ for managed treatments for 40 spacing as compared to the $120 \mathrm{~cm}$ depth. Concerning water table management under rice crop, the $40 \mathrm{~cm}$ depth of controlled drainage saved about 18.21 and $27.01 \%$ of nitrate for 20 and 40m lateral distance as compared to 120 cm depth in 2019 season. These results fall in line with findings of Wahba et al., (2001\&2008) and Skagges et al., (2010).

\section{Rice Yield}

The crop growth and subsequently the yield primarily depend on the favorable environment in the root zone, rooting depth, sensitivity of crop for water. The poor root proliferation may be rendered to the high groundwater, causing an extreme defect on oxygen and the domination of reduction process reasonable to nutrients unavailability and root diseases.

Results in Table (6) showed that there were significant differences in the rice grain yield as compared to the control. Rice grain yield for 20-m spacing increased by about 996, and $261 \mathrm{kgfed}^{-1}$ for controlled drainage at 40 and $80 \mathrm{~cm}$ depth, respectively as compared to conventional drainage in the first season, meanwhile with $40 \mathrm{~m}$ spacing the yield increased by 901 and $330 \mathrm{~kg} \mathrm{fed}^{-1}$ under controlled drainage at 40 and $80 \mathrm{~cm}$ depth of water table as compared to uncontrolled drainage in the same season. 
El-Ghannam, et al.,

Table (6): Effect of different applied treatments on rice yields $\left(\mathrm{kg} \mathrm{fed}^{-1}\right.$.)

\begin{tabular}{|c|c|c|c|c|c|c|c|}
\hline \multicolumn{2}{|c|}{ Treatments } & \multirow[b]{2}{*}{$\begin{array}{l}\text { Panicle } \\
\text { length } \mathrm{cm}\end{array}$} & \multirow[b]{2}{*}{$\begin{array}{l}1000 \text { grain } \\
\text { weight (g) }\end{array}$} & \multirow[b]{2}{*}{$\begin{array}{l}\text { Plant height } \\
\text { (cm) }\end{array}$} & \multirow[b]{2}{*}{$\begin{array}{l}\text { Rice grain } \\
\left(\text { kgfed }^{-1}\right)\end{array}$} & \multirow[b]{2}{*}{$\begin{array}{c}\text { Straw yield } \\
\left(\text { kgfed }^{-1}\right)\end{array}$} & \multirow{2}{*}{$\begin{array}{c}\text { Biological } \\
\text { yield } \\
\text { (Kg fed }^{-1} \text { ) }\end{array}$} \\
\hline $\begin{array}{c}\text { Drains } \\
\text { distance } \\
(\mathrm{m})\end{array}$ & $\begin{array}{l}\text { Ground water } \\
\text { depth }(\mathbf{c m})\end{array}$ & & & & & & \\
\hline \multirow{5}{*}{20} & \multicolumn{7}{|c|}{$1^{\text {st }}$ season } \\
\hline & 40 & $21.77 \mathrm{a}$ & $26.17 \mathrm{a}$ & $120.0 \mathrm{a}$ & $4832.6 \mathrm{a}$ & $3422.7 \mathrm{a}$ & $8255.3 \mathrm{a}$ \\
\hline & 80 & $18.70 \mathrm{~b}$ & $23.20 \mathrm{~b}$ & $118.0 a b$ & $4097.0 \mathrm{~b}$ & $2991.0 \mathrm{~b}$ & 7088 b \\
\hline & 120 & $16.73 \mathrm{c}$ & $20.70 \mathrm{c}$ & $117.0 \mathrm{~b}$ & $3836.0 \mathrm{c}$ & $2815.0 \mathrm{C}$ & $6651 \mathrm{c}$ \\
\hline & Mean & 19.07 & 23.36 & 118.3 & 4255.22 & 3076.2 & 7331.42 \\
\hline \multirow{6}{*}{40} & 40 & $20.20 \mathrm{a}$ & $23.40 \mathrm{a}$ & $117.3 \mathrm{a}$ & $4321.3 \mathrm{a}$ & $3150.0 \mathrm{a}$ & $7471.3 \mathrm{a}$ \\
\hline & 80 & $18.27 \mathrm{~b}$ & $22.13 \mathrm{~b}$ & $114.0 \mathrm{~b}$ & $3747.3 \mathrm{~b}$ & $2886.0 \mathrm{~b}$ & $6633.3 \mathrm{~b}$ \\
\hline & 120 & $15.50 \mathrm{c}$ & $20.27 \mathrm{c}$ & $113.0 \mathrm{~b}$ & $3420.0 \mathrm{c}$ & $2563.0 \mathrm{c}$ & $5983 \mathrm{c}$ \\
\hline & Mean & 17.99 & 21.93 & 114.8 & 3829.56 & 2866.3 & 6695.86 \\
\hline & LSD at $5 \%$ & 0.86 & 0.85 & 1.6 & 15.33 & 7.9 & 4.8 \\
\hline & LSD at $1 \%$ & 24 & 1.24 & 2.4 & 22.30 & 11.5 & 7.0 \\
\hline \multirow{5}{*}{20} & \multicolumn{7}{|c|}{$2^{\text {nd }}$ season } \\
\hline & 40 & $23.2 \mathrm{a}$ & $27.5 \mathrm{a}$ & $125.0 \mathrm{a}$ & $4897.0 \mathrm{a}$ & $3447.0 \mathrm{a}$ & $8344.0 \mathrm{a}$ \\
\hline & 80 & $19.5 \mathrm{~b}$ & $25.1 \mathrm{~b}$ & $122.0 \mathrm{a}$ & $4139.3 \mathrm{~b}$ & $3046.0 \mathrm{c}$ & $7185.0 \mathrm{~b}$ \\
\hline & 120 & $17.8 \mathrm{c}$ & $23.1 \mathrm{c}$ & $118.0 \mathrm{~b}$ & $3878.0 \mathrm{~b}$ & $3150.0 \mathrm{~b}$ & $7028.0 \mathrm{c}$ \\
\hline & Mean & 20.167 & 25.233 & 121.667 & 4304.7 & 3214.30 & 7519.0 \\
\hline \multirow{6}{*}{40} & 40 & $21.5 \mathrm{a}$ & $26.3 \mathrm{a}$ & $121.0 \mathrm{a}$ & $4320.0 \mathrm{a}$ & $3312.0 \mathrm{a}$ & $7632.0 \mathrm{a}$ \\
\hline & 80 & $18.7 \mathrm{~b}$ & $24.4 \mathrm{~b}$ & $117.6 \mathrm{~b}$ & $3750.0 \mathrm{a}$ & $2943.0 \mathrm{~b}$ & $6693.0 \mathrm{~b}$ \\
\hline & 120 & $16.9 \mathrm{c}$ & $22.6 \mathrm{c}$ & $114.3 \mathrm{c}$ & $3480.0 \mathrm{a}$ & $2933.0 \mathrm{C}$ & $6413.0 \mathrm{c}$ \\
\hline & Mean & 19.033 & 24.456 & 117.667 & 3850.0 & 3062.7 & 6912.7 \\
\hline & LSD at $5 \%$ & 0.255 & 0.441 & 2.27 & 13.33 & 2.2 & 4.8 \\
\hline & LSD at $1 \%$ & 0.371 & 0.642 & 3.30 & 19.35 & 3.2 & 7.0 \\
\hline
\end{tabular}

In the second season, the highest values of grain yield were 4897 and 4320 $\mathrm{kg}$ fed-1 for controlled drainage at $40 \mathrm{~cm}$ depth under 20 and $40 \mathrm{~m}$ spacing of lateral, while the lowest ones were 3878 and $3480 \mathrm{~kg} \mathrm{fed}^{-1}$ for free drainage under the same spaces of lateral respectively.

There was a marked variation between the treatments whereas the controlled drainage at $40 \mathrm{~cm}$ depth led to an increase in the grain yield by 25.96 and $26.35 \%$ for 2018 and 26.28 and $24.14 \%$ for 2019 under 20 and $40 \mathrm{~m}$ lateral spacing, respectively. From the abovementioned discussion, it can be concluded that the controlled drainage may give more profit than the uncontrolled one. The obtained results are agreed with those reported by Elghannam, (2015), Skagges et al., (2012) and Sobeih et al., (2017).
Applied water and productivity of irrigation water (PIW)

Results in Table (7) revealed that, narrow drain spacing $(20 \mathrm{~m})$ and/or deep ground water $(120 \mathrm{~cm})$ had received the highest amount of irrigation water as compared to wider drain spacing $(40 \mathrm{~m})$ and/or shallowing ground water $(40 \mathrm{~cm}$ or $80 \mathrm{~cm}$ ). This is due to, under narrow spacing and/or deep groundwater, high amount of drainage water was recorded. On the other hand, wider drain spacing and/or rising groundwater was stored more water. Data showed that, controlled drainage at 40 and $80 \mathrm{~cm}$ depth resulted in water saving amount by 21.07 and $14.94 \%$ under 20-m spacing and 19.59 and $11.16 \%$ under $40 \mathrm{~m}$ spacing, in the first season and 22.74 and $14.62 \%$ under $20 \mathrm{~m}$ spacing and 25.35 and $11.06 \%$ under $40 \mathrm{~m}$ spacing, respectively in the second season as compared to $120 \mathrm{~cm}$ depth. 
Table (7): Water applied $\left(\mathrm{m}^{3} \mathrm{fed}^{-1}\right)$ and productivity of irrigation water (PIW, $\mathrm{kgm}^{-3}$ ) of rice yield as affected by different treatments.

\begin{tabular}{|c|c|c|c|c|c|c|}
\hline \multicolumn{2}{|c|}{ Treatments } & \multirow[b]{2}{*}{$\begin{array}{c}\text { Water } \\
\text { applied } \\
\left(\mathrm{m}^{3} \mathrm{fed}^{-1}\right)\end{array}$} & \multicolumn{2}{|c|}{ Water saving } & \multicolumn{2}{|c|}{$\mathrm{PIW}, \mathrm{kg} \mathrm{m}^{-3}$} \\
\hline $\begin{array}{c}\text { Drains } \\
\text { distance }(m)\end{array}$ & $\begin{array}{c}\text { Ground } \\
\text { water depth } \\
(\mathrm{cm})\end{array}$ & & $\left(m^{3} \mathrm{fed}^{-1}\right)$ & $\%$ & Grain & Straw \\
\hline \multicolumn{7}{|c|}{$1^{\text {st }}$ season } \\
\hline \multirow[b]{3}{*}{20} & 40 & 5150 & 1375 & 21.07 & 0.94 & 0.66 \\
\hline & 80 & 5550 & 975 & 14.94 & 0.74 & 0.54 \\
\hline & 120 & 6525 & - & - & 0.59 & 0.43 \\
\hline \multirow[b]{3}{*}{40} & 40 & 4720 & 1150 & 19.59 & 0.92 & 0.67 \\
\hline & 80 & 5215 & 655 & 11.16 & 0.72 & 0.55 \\
\hline & 120 & 5870 & - & - & 0.58 & 0.44 \\
\hline \multicolumn{7}{|c|}{$2^{\text {nd }}$ season } \\
\hline \multirow[b]{3}{*}{20} & 40 & 5180 & 1525 & 22.74 & 0.95 & 0.67 \\
\hline & 80 & 5725 & 980 & 14.62 & 0.72 & 0.53 \\
\hline & 120 & 6705 & - & - & 0.58 & 0.47 \\
\hline \multirow[b]{3}{*}{40} & 40 & 4632 & 1573 & 25.35 & 0.93 & 0.72 \\
\hline & 80 & 5519 & 686 & 11.06 & 0.68 & 0.53 \\
\hline & 120 & 6205 & - & - & 0.56 & 0.47 \\
\hline
\end{tabular}

Data in Table (7) indicated that productivity of irrigation water (PIW) of rice yields were greatly affected by different treatments in both seasons. Data showed that the values of PIW for rice grain yield were ranged from 0.56 to $0.95 \mathrm{kgm}^{-3}$ with all treatments. The high values of PIW were observed with $20 \mathrm{~m}$ drain spacing and/or $120 \mathrm{~cm}$ groundwater depth compared to $40 \mathrm{~m}$ spacing with $40 \mathrm{~cm}$ and $/$ or $80 \mathrm{~cm}$ groundwater depth. The mean values of PIW for rice grain yield were $0.94,0.74$ and $0.59 \mathrm{~kg} \mathrm{~m}^{-3}$ with $20 \mathrm{~m}$ spacing and $0.92,0.72$ and $0.58 \mathrm{~kg}$ $\mathrm{m}^{-3}$ with $40 \mathrm{~m}$ spacing for controlled water table at 40,80 and $120 \mathrm{~cm}$, respectively in the first season. For the second season, the values were $0.95,0.72$ and $0.58 \mathrm{~kg} / \mathrm{m}^{-3}$ with $20 \mathrm{~m}$ spacing and $0.93,0.68$ and $0.56 \mathrm{~kg} \mathrm{~m}^{-3}$ with $40 \mathrm{~m}$ spacing, respectively.

\section{Salt balance}

The main source of fresh irrigation water in the studied area is Brenbial branch canal where the salinity average of irrigation water was 0.7 and $0.8 \mathrm{dSm}^{-1}$ for first and second seasons, respectively. The salts added to the soil from irrigation water (Table 8 and Fig. 1) were estimated as; 2307.2, 2486.4 and $2923.2 \mathrm{kgfed}^{-1}$ with $20 \mathrm{~m}$ spacing and 2128.0, 2336.3 and $2629.8 \mathrm{kgfed}^{-1}$ with $40 \mathrm{~m}$ spacing for ground water of 40,80 and $120 \mathrm{~cm}$, respectively in the first season. The corresponding values for the second season (Table 8 and Fig. 2) were 2652.2, 2931.2 and $3433.0 \mathrm{kgfed}^{-1}$ with 20$\mathrm{m}$ spacing and 2371.6, 2825.7 and 3177.0 $\mathrm{kgfed}^{-1}$ with $40-\mathrm{m}$ spacing, respectively. Salinity average of drainage water were 1.7, 1.6 and $1.45 \mathrm{dSm}^{-1}$ with $20-\mathrm{m}$ spacing 
and $1.95,1.8$ and $1.7 \mathrm{dSm}^{-1}$ with $40-\mathrm{m}$ spacing for ground water of 40,80 and $120 \mathrm{~cm}$, respectively in the first season and were 1.65, 1.4 and $1.25 \mathrm{dSm}^{-1}$ with 20 $\mathrm{m}$ spacing and $1.55,1.4$ and $1.0 \mathrm{dSm}^{-1}$ with 40-m spacing, respectively in the second season. Data in Table 8 and illustrated in the Figure 1 showed that the salts removed from the soil with drainage water were 1008.6, 1136.6 and 1532.4 kgfed $^{-1}$ with 20-m spacing and 1067.0, 1201.5 and $1596.6 \mathrm{kgfed}^{-1}$ with $40-\mathrm{m}$ spacing for groundwater of 40,80 and $120 \mathrm{~cm}$, respectively in the first season. The corresponding values were 984.6, 1025.9 and $1341.2 \mathrm{kgfed}^{-1}$ with $20-\mathrm{m}$ spacing and 826.3, 988.3 and 992.6 $\mathrm{kgfed}^{-1}$ with $40-\mathrm{m}$ spacing, respectively in the second season (Fig. 2).

\section{Economic evaluation}

Data in Table 9 indicated that the highest values of net return, economic efficiency and net return from water unit for rice yields were recorded with narrow drain spacing, while, the lowest values were recorded with wider drain spacing in both seasons. The maximum values of net return (10570 and 10833 L.E. fed $\left.{ }^{-1}\right)$, economic efficiency (1.16 and 1.19) and net return from water unit (2.05 and 2.09 L.E. $\mathrm{m}^{-3}$ ) of rice grain yield and (1.99 and 2.02 L.E. $^{-3}$ ) for biological yield were recorded under $20-\mathrm{m}$ spacing with $40 \mathrm{~cm}$ groundwater depth in the first and second seasons, respectively. While, the minimum values were (5236 and 5513 L.E. fed $\left.{ }^{-1}\right),(0.60$ and 0.63$)$ and $(0.89$ and 0.89 L.E. $\mathrm{m}^{-3}$ ) were achieved with $40-\mathrm{m}$ spacing under $120 \mathrm{~cm}$ groundwater depth, respectively.

Table (8): Effect of distance and depth of lateral treatments on salt balance

\begin{tabular}{|c|c|c|c|c|c|c|}
\hline \multirow[b]{2}{*}{ Variables } & \multicolumn{3}{|c|}{ 20-m spacing } & \multicolumn{3}{|c|}{ 40-m spacing } \\
\hline & $\begin{array}{l}40 \mathrm{~cm} \\
\text { depth }\end{array}$ & $\begin{array}{l}80 \mathrm{~cm} \\
\text { depth }\end{array}$ & $\begin{array}{l}120 \mathrm{~cm} \\
\text { depth }\end{array}$ & $\begin{array}{l}40 \mathrm{~cm} \\
\text { depth }\end{array}$ & $\begin{array}{l}80 \mathrm{~cm} \\
\text { depth }\end{array}$ & $\begin{array}{l}120 \mathrm{~cm} \\
\text { depth }\end{array}$ \\
\hline \multicolumn{7}{|c|}{ First season } \\
\hline Irrigation water $\left(\mathrm{m}^{3} \mathrm{fed}^{-1}\right)$ & 5150 & 5550 & 6525 & 4750 & 5215 & 5870 \\
\hline EC IW $\left(\mathrm{dSm}^{-1}\right)$ & 0.7 & 0.7 & 0.7 & 0.7 & 0.7 & 0.7 \\
\hline Salt added (kgfed. $\left.{ }^{-1}\right)$ & 2307.20 & 2486.40 & 2923.20 & 2128.00 & 2336.32 & 2629.76 \\
\hline Drainage water $\left(\mathrm{m}^{3} \mathrm{fed}^{-1}\right)$ & 927 & 1110 & 1651.25 & 855 & 1043 & 1467.5 \\
\hline EC Dw $\left(\mathrm{dSm}^{-1}\right)$ & 1.7 & 1.6 & 1.45 & 1.95 & 1.8 & 1.7 \\
\hline Salt removed $\left(\mathrm{kgfed}^{-1}\right)$ & 1008.58 & 1136.64 & 1532.36 & 1067.04 & 1201.54 & 1596.64 \\
\hline Salt residual (kgfed. $\left.{ }^{-1}\right)$ & 1298.62 & 1349.76 & 1390.84 & 1060.96 & 1134.78 & 1033.12 \\
\hline \multicolumn{7}{|c|}{ Second season } \\
\hline Irrigation water $\left(\mathrm{m}^{3} \mathrm{fed}^{-1}\right)$ & 5180 & 5725 & 6705 & 4632 & 5519 & 6205 \\
\hline EC Iw $\left(\mathrm{dSm}^{-1}\right)$ & 0.8 & 0.8 & 0.8 & 0.8 & 0.8 & 0.8 \\
\hline Salt added (kgfed. ${ }^{-1}$ ) & 2652.16 & 2931.20 & 3432.96 & 2371.58 & 2825.73 & 3176.96 \\
\hline Drainage water $\left(\mathrm{m}^{3} \mathrm{fed}^{-1}\right)$ & 932.4 & 1145 & 1676.5 & 833 & 1103 & 1551 \\
\hline EC Dw $\left(\mathrm{dSm}^{-1}\right)$ & 1.65 & 1.4 & 1.25 & 1.55 & 1.4 & 1 \\
\hline Salt removed (kgfed..$\left.^{-1}\right)$ & 984.61 & 1025.92 & 1341.20 & 826.34 & 988.29 & 992.64 \\
\hline Salt residual (kgfed..$^{-1}$ ) & 1667.55 & 1905.28 & 2091.76 & 1545.25 & 1837.44 & 2184.32 \\
\hline
\end{tabular}




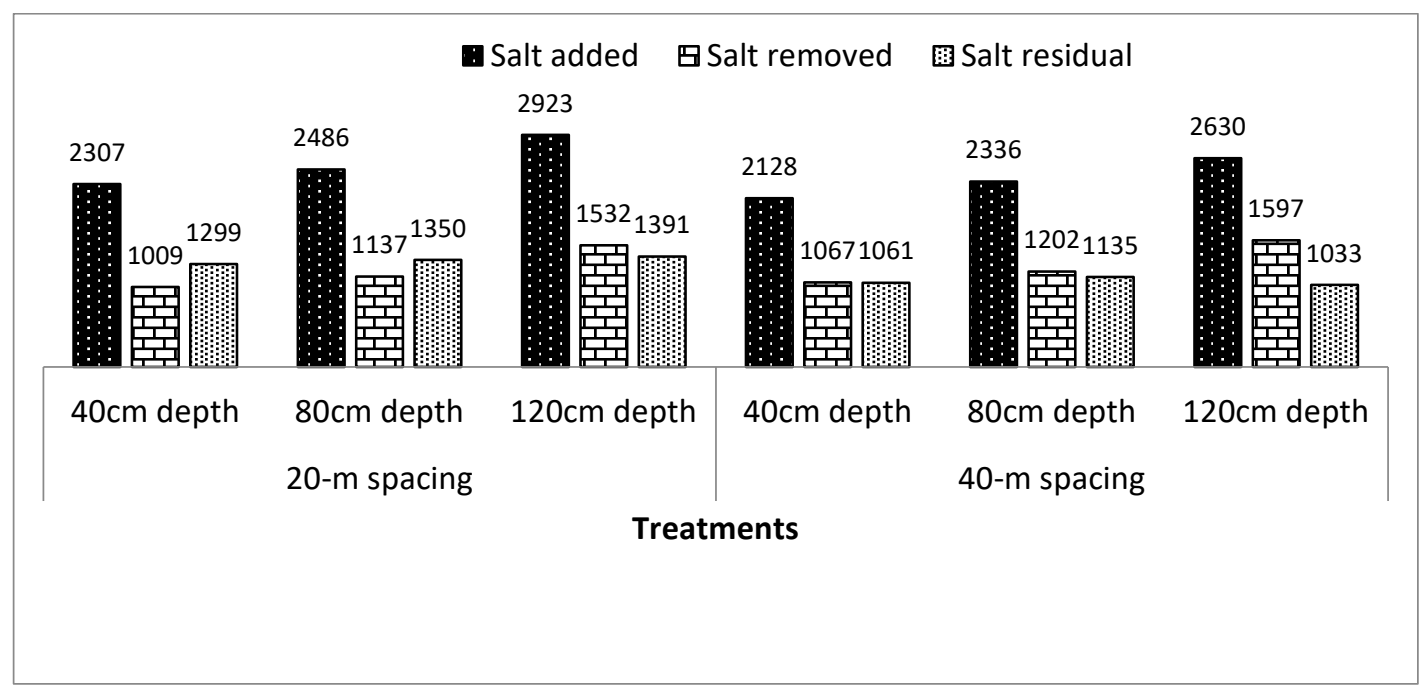

Fig. (1): Salt balance as affected by drain spacing and ground water depth in the $1^{\text {st }}$ season

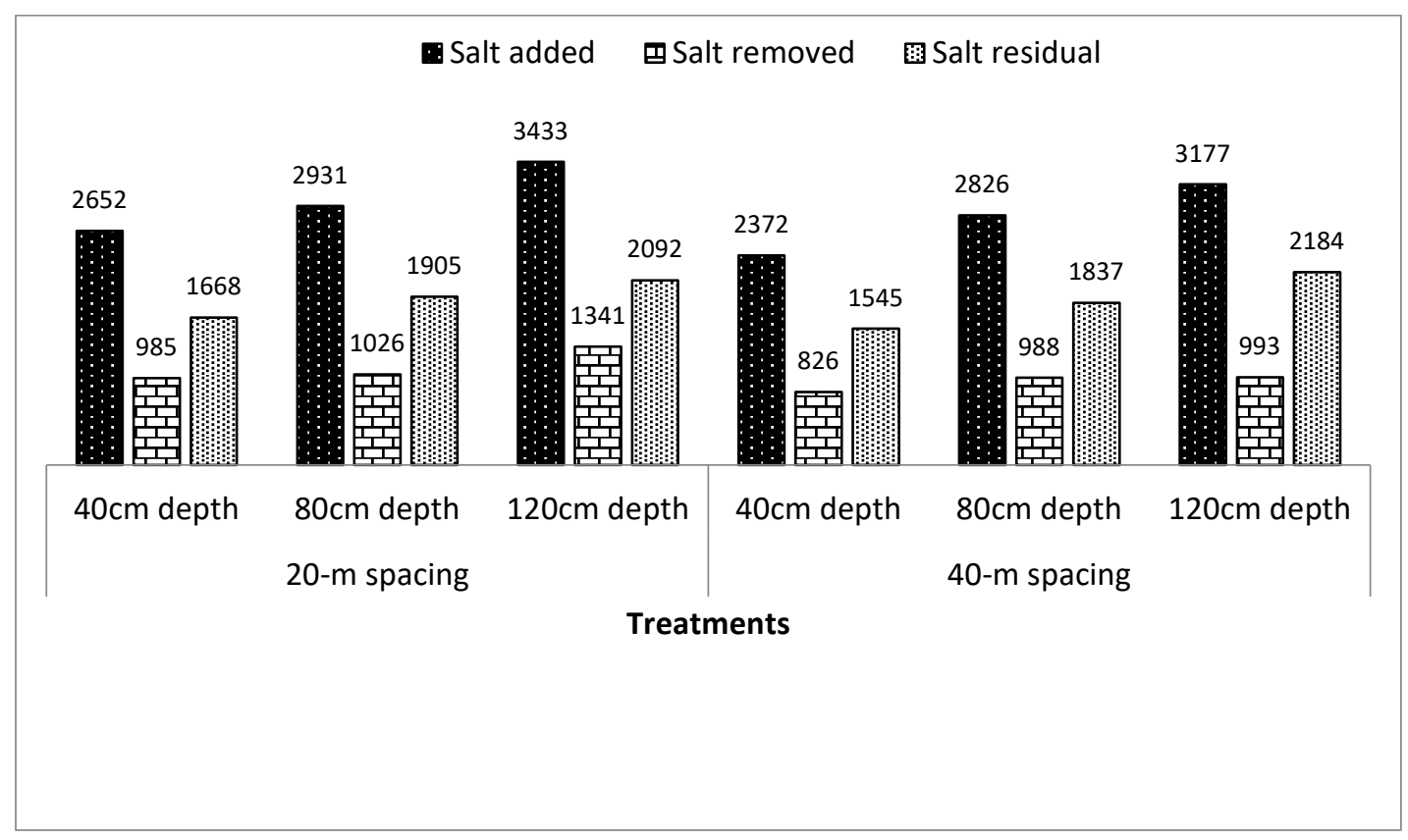

Fig. (2): Salt balance as affected by drain spacing and ground water depth in the $2^{\text {nd }}$ season. 
El-Ghannam, et al.,

Table (9): Total revenue, total cost, net return, economic efficiency and net return from water unit for rice yields with different treatments.

\begin{tabular}{|c|c|c|c|c|c|c|}
\hline \multirow[b]{2}{*}{ Variables } & \multicolumn{3}{|c|}{ 20-m spacing } & \multicolumn{3}{|c|}{ 40-m spacing } \\
\hline & $\begin{array}{l}40 \mathrm{~cm} \\
\text { depth }\end{array}$ & $\begin{array}{l}80 \mathrm{~cm} \\
\text { depth }\end{array}$ & $\begin{array}{c}120 \mathrm{~cm} \\
\text { depth }\end{array}$ & $\begin{array}{l}40 \mathrm{~cm} \\
\text { depth }\end{array}$ & $\begin{array}{l}80 \mathrm{~cm} \\
\text { depth }\end{array}$ & $\begin{array}{l}120 \mathrm{~cm} \\
\text { depth }\end{array}$ \\
\hline \multicolumn{7}{|c|}{ First season } \\
\hline Grain yield revenue (LE.fed $\left.{ }^{-1}\right)$ & 19328 & 16386 & 15344 & 17284 & 15000 & 13680 \\
\hline Straw yield revenue (LE. fed ${ }^{-1}$ ) & 342 & 299 & 282 & 315 & 289 & 256 \\
\hline Total revenue (LE. fed ${ }^{-1}$ ) & 19670 & 16686 & 15626 & 17599 & 15289 & 13936 \\
\hline Treatments cost $\left(\right.$ LEFed $\left.^{-1}\right)$ & 600 & 500 & 400 & 300 & 250 & 200 \\
\hline Costs of VAP (LE fed ${ }^{-1}$ ) & 4000 & 4000 & 4000 & 4000 & 4000 & 4000 \\
\hline Land rent for summer season & 4500 & 4500 & 4500 & 4500 & 4500 & 4500 \\
\hline Total cost (LE. fed $\left.{ }^{-1}\right)$ & 9100 & 9000 & 8900 & 8800 & 8750 & 8700 \\
\hline Net return (L.E. fed ${ }^{-1}$ ) & 10570 & 7686 & 6726 & 8799 & 6539 & 5236 \\
\hline Water applied $\mathbf{m}^{-3} \mathrm{fed}^{-1}$ & 5150 & 5550 & 6525 & 4750 & 5215 & 5870 \\
\hline Net return from water unit (L.E.m ${ }^{-3}$ ) for G.y & 2.05 & 1.38 & 1.03 & 1.85 & 1.25 & 0.89 \\
\hline Net return from water unit (L.E.m ${ }^{-3}$ ) for B.y & 1.99 & 1.33 & 0.99 & 1.79 & 1.19 & 0.85 \\
\hline Economic efficiency for Gy & 1.16 & 0.85 & 0.76 & 1.00 & 0.75 & 0.60 \\
\hline Economic efficiency for By & 1.12 & 0.82 & 0.72 & 0.96 & 0.71 & 0.57 \\
\hline \multicolumn{7}{|c|}{ Second season } \\
\hline Grain yield revenue (LE.fed-1) & 19588 & 16554 & 15512 & 17280 & 15000 & 13920 \\
\hline Straw yield revenue (LE. fed-1) & 345 & 305 & 315 & 331 & 294 & 293 \\
\hline Total revenue (LE. fed-1) & 19933 & 16859 & 15827 & 17611 & 15294 & 14213 \\
\hline Treatments cost (LEFed-1) & 600 & 500 & 400 & 300 & 250 & 200 \\
\hline Costs of VAP (LE fed ${ }^{-1}$ ) & 4000 & 4000 & 4000 & 4000 & 4000 & 4000 \\
\hline Land rent for summer season & 4500 & 4500 & 4500 & 4500 & 4500 & 4500 \\
\hline Total cost (LE. fed-1) & 9100 & 9000 & 8900 & 8800 & 8750 & 8700 \\
\hline Net return (L.E. fed-1) & 10833 & 7859 & 6927 & 8811 & 6544 & 5513 \\
\hline Water applied m-3fed-1 & 5180 & 5725 & 6705 & 4632 & 5519 & 6205 \\
\hline Net return from water unit (L.E.m-3) for Gy & 2.09 & 1.37 & 1.03 & 1.90 & 1.19 & 0.89 \\
\hline Net return from water unit (L.E.m-3) for By & 2.02 & 1.32 & 0.98 & 1.83 & 1.13 & 0.84 \\
\hline Economic efficiency for Gy & 1.19 & 0.87 & 0.78 & 1.00 & 0.75 & 0.63 \\
\hline Economic efficiency for By & 1.15 & 0.84 & 0.74 & 0.96 & 0.71 & 0.6 \\
\hline
\end{tabular}

Price of grain yield $=4200 \mathrm{LE}_{\text {ton }}^{-1}$ and $100 \mathrm{LE}_{\text {ton }}^{-1}$ for straw in both seasons

All price according to the local market (LE) $\quad G y=$ Grain yield

$V A P=$ variable costs of agricultural practices

$B y=$ Biological yield

This is due to improved soil properties under narrow drain spacing which caused water-air balance in the root zone, which in turn led to increase the rice yields. Also data indicated that, the controlled of groundwater near the root zone $(40-\mathrm{cm}$ and $80 \mathrm{~cm})$ under rice cultivation resulted in high values of net return, economic efficiency and net return from water unit. These increments in production of rice crop could be attributed to that under controlled of 
groundwater, which accompanied with less irrigation water, more energy is forced to extract more water with its content of fertilizers, which in turn resulted in decreasing the withdrawn of fertilizers. Similar results were obtained by (Antar, 2013).

\section{Conclusion}

The obtained results of the current study showed that narrow drain spacing of $20 \mathrm{~m}$ and water table depth to $0.4 \mathrm{~m}$ was more efficient according to the concept of water saving, nitrate saving, productivity of irrigation water, rice yields, net return, net return from water and economic efficiency compared to wider drain spacing with $1.2 \mathrm{~m}$ ground water depth. Therefore, it can be concluded that the treatment of controlled drainage gave more profit than the uncontrolled one.

\section{REFERENCES}

Abdalla, M.A.M. (2000). Drainage parameters and water management for light textured soils in Qaliubia Governorate. Ph.D. Thesis, Fca. of Agric. Ain Shams Univ., Egypt.

Ali, M. H., M. R. Hoque, A. A. Hassan and A. Khair (2007). Effects of deficit irrigation on yield, water productivity, and economic returns of wheat. Agricultural Water Management 92 (3): 151- 161.

Alizadeh, M., P. Afrasiab, M.R. Yazdani, A. Liaghat and $M$. Delbari (2018). Determination of subsurface drainage spacing using field data in paddy fields of Guilan Province. Iranian journal of soil and water research, Vol. 49. Issue 3: 607-617

Antar, A. S. (2013). Nitrate leaching losses into field tile drain as affected by land leaching and $\mathrm{N}$-fertilizer under wheat crop. J. Agric. Res. Kafrelsheikh Univ., (4): 616-635.
Antar, S.A. (2007). Nitrate transport in clay soils and its losses into field drains tiles from urea applied for sugar beet. J. Agric. Sci. Mansoura Univ., 32 (6): 4987-4998.

Armstrong, A.B., G.R. Pearce, D.W. Rycroft and T.W. Tanton (1990). Field testing of a new reclamation technique for saline clay soils. Symposium on Land Drainage for Salinity Control in Arid and Semi-Arid Regions. DRI., Feb. 25 to 2nd March, Cairo, Egypt. 2: 89-98.

Ayars, J.E., E. Christen, P. Services and J. Hornbuckle (2006.). Controlled drainage for improved water management in arid zone irrigated agriculture. Journal of Agric. Water Manage., Vol. 86: 128-139.

Campbell, D.J. (1994). Determination and use of bulk density in relation to soil compaction. In Soane and Ouwerk (Eds). Soil compaction in crop production. Elsever, London and Amsterdam.

Campus, M. (2019). Water table management and fertilizer application impacts on $\mathrm{CO}$, $\mathrm{N} 2 \mathrm{O}$ and $\mathrm{CH} 4$ fluxes in a corn agro-ecosystem. Sci. Rep. 113. https://doi.org/10.1038/s41598-01939046-z.

Cottenie, A., M. Verloo, L. Mjkiekens, G. Velghe and R. Comertynck (1982). Chemical analysis of plant and soil. Lab. Anal. And Agrochem. State Univ., Gent., Belgium, Chapter 2 and 3, pp. 14-54.

Craft, K.J., M.J. Helmers, R.W. Malone, C.H. Pederson and L.R. Schott (2018). Effects of subsurface drainage systems on water and nitrogen footprints simulated with RZWQM2. Trans. ASABE 61, 245-261. https://doi.org/10.13031/trans.12300

Dieleman, P. J. and B. D. Trafford (1976). Drainage testing. Irrigation and Drainage Paper No. 28. FAO, Rome. 
Drury, C. F., C. S. Tan, J. D. Gaynor, T. O. Oloya and T. W. Welacky (1996). Influence of controlled drainagesubirrigation on surface and tile drainage nitrate loss. J. Environ. Qual. 25: 317-324.

Drury, C.F., C.S. Tan, W.D. Reynolds, T.W. Welacky, T.O. Oloya and J.D. Gaynor (2009). Managing Tile Drainage, Subirrigation, and Nitrogen Fertilization to Enhance Crop Yields and Reduce Nitrate Loss. J. Environ. Qual. 38, 1193-1204.

El-Ghannam, M.K. (2016). Study the impact of controlled subsurface drainage on water saving, crop yield and soil salinity in North Nile Delta Ph.D. Thesis, Fac. of Agriculture Kafr elsheikh Univ. Egypt.

El-Ghannam, M.K., M.E. AboWaly, S.A. Gaheen, F.F. Karajeh and A.A. Gendy (2016). Controlled drainage effects on nitrate leaching, salinity build-up and sugar beet production (Egypt). Merit Res. J. Agric. Sci. Soil Sci. 4 (2): 2332.

Evans, R.O., J.W. Gilliam and R.W. Skaggs (1996). Controlled Drainage Management Guidelines for Improving Drainage Water Quality. North Carolina Coop. Ext. Service Publ. AG433 (1991 first issue, 1996 latest electronic revision.

Feser, S.E., J.S. Strock, G.R. Sands and A.S. Birr (2010). Controlled drainage to improve edge-of-field water quality in southwest Minnesota, USA. In Drainage IX: Proceedings of the Ninth International Drainage Symposium, Quebec City, QC, June 13-16, 2010. St. Joseph, MI: ASABE.

Gupta, S.K., D.P. Sharma and K.V.G.K. Rao (1998). Performance indicators for drainage evaluation and cause analysis. Drainage in the 21st Century. Proceedings of the 7th Annual Drainage Symposium, March 8-10, 1998, Orlando, Florida, U.S.A
Helmers, M., R. Christianson, G. Brenneman, D. Lockett and C. Pederson (2012). Water table, drainage, and yield response to drainage water management in southeast lowa. https://doi.org/10.2489/jswc.67.6.495

Hornbuckle, J.W. (2003). The impact of subsurface drainage design and management on salinity and irrigation water use in a semi-arid environment. Ph.D. Thesis. University of New England, Armidale.

Ibrahim, S.M., S.A. Gaheen, M.A. Koriem and A.S. Antar (2002). Atrazine and nitrate transport through a clay soil into subsurface tile drains of different spacings. J. Agric. Res. Tanta Univ., 29 (2): 335-353.

IRRI (2020). International Rice Research Institute, https://www.irri.org/worldfood-day-2020.

Javani, H., A. Liaghat, A. Hassanoghli and R. Henk (2018). Managing controlled drainage in irrigated farmers' fi elds : A case study in the Moghan plain , Iran. Agric. Water Manag. 208, 393-405. https://doi.org/10.1016/j.agwat.2018.06 .037

Lavaire, T., L.E. Gentry, M.B. David and R.A. Cooke (2017). Fate of water and nitrate using drainage water management on tile systems in eastcentral Illinois. Agric. Water Manag.191, 218-228. https://doi.org/10.1016/j.agwat.2017.06 .004.

Liu, Y., M.A. Youssef, G.M. Chescheir, T.W. Appelboom, C.A. Poole, C. Arellano and R.W. Skaggs (2019). Effect of controlled drainage on nitrogen fate and transport for a subsurface drained grass field receiving liquid swine lagoon effluent. Agric. Water Manag. 217, 440 https://doi.org/10.1016/j.agwat.2019.02 .018. 
Lu, B., G. Shao, S. Yu, S. Wu and X. Xie (2016). The Effects of Controlled Drainage on $\mathrm{N}$ Concentration and Loss in Paddy Field. J. Chem. 2016 https://doi.org/10.1155/2016/1073691.

Madani, A. and P. Brenton (1994). Effect of drain spacing on subsurface drainage performance in a shallow, slowly permeable soil Canadian Agricultural Engineering. 37(1): 9-12.

Masoud, F.I. (1969). Principles of Agricultural Irrigation. Dar Elmatbouat Elgadidah, Alexandria (In Arabic).

Page, A.L., R. H. Miller and D. R. Keeney (1982). Methods of Soil Analysis. Part 2: Chemical and Microbiological Properties, $2^{\text {nd }}(\mathrm{Ed})$. Amer Soc. of Agron., Madison, Wisconsin, U.S.A.

Ramadan, S.A., A.S.A. Abdel-Mawgoud and A.A.S. Gendy (2009). AgroChemical fertilizers losses by subsurface flow in the irrigated clay soil. Minufiy J. Agric. Res. 29 (5): 1227-1242.

Skaggs, R.W., M.A. Youssef, J.W. Gilliam and R.O. Evans (2010). Effect of controlled drainage on water and nitrogen balances in drained lands. Trans. Asabe 53: 1843-1850.

Skaggs, W.R., N.R. Fausey and R.O. Evans (2012). Drainage water management. J. Soil Water Conserv. 67.

https://doi.org/10.2489/jswc.67.6.167A.
Snedecor, G.A. and W.C. Cochran (1980). Statistical method 6ed Oxford and IBH. Publishing Co. Calcutta India.

Sobeih, M.M., N.E. El-arabi, D.Y. Helal and B.S. Awad (2017). Management of water resources to control groundwater levels in the southern area of the western Nile delta, Egypt. Water Sci. 31, 137-150. https://doi.org/10.1016/j.wsj.2017.09.001

Tan, C. S., C. F. Drury, J.D. Gaynor and T. W. Welacky (1993). Integrated soil, crop and water management system to abate herbicide and nitrate contamination of the Great Lakes. Water Sci. Technol. 28: 497-507.

Taylor GS (1960). Drainable porosity evaluation from outflow measurements and its use in drawdown equations. Soil Sci 90:338345.

Wahba, M.S., M.A. EL-Ganainy and M. H. Amer (2008). Water table management strategies for irrigation water saving. Twelfth International Water Technology Conference, IWTC12 2008, Alexandria, Egypt.

Wahba, M. S., M. A. El Ganainy, M. S. Abdel Dayem, A. Gobran and H. Kandil (2001). Controlled drainage effects on water quality under semi arid conditions in the western delta of Egypt Irrig. and Drainage 50(4): 295 308. 
تأثير مسافات حقليات الصرف وعمق الماء الأرضي علي بعض العلاقات المائية وخواص

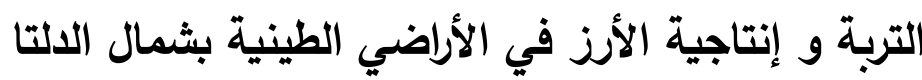

محمد خطاب الغنام(")، رامي محمد خليفة(ץ)، بطرس بشري ميخائيل(")

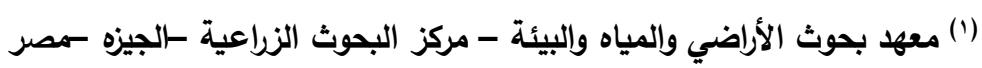

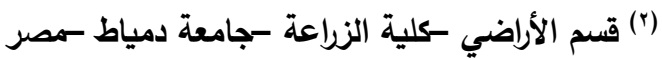
مركز البحوث و التدريب في الأرز -معهل بحوث المحاصيل الحقلية- مركز البحوث الزراعية - الجيزه -مصر

الملخص

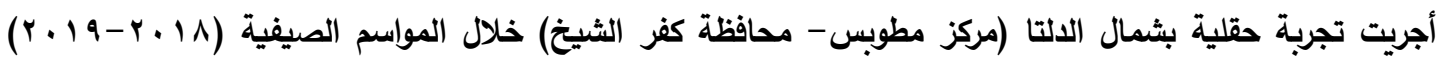

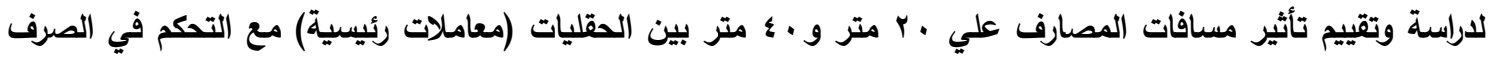

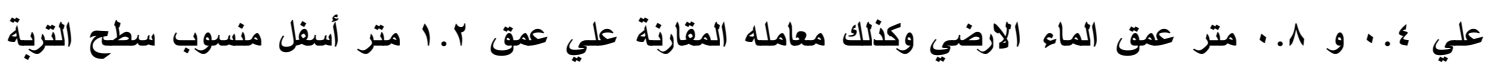
(معاملات شقية) تحت ظروف زراعة الأرز علي خواص التربة ، فقد النترات، ترشيد المياه، إنتاجية الأرز والعائد الأقتصادي. أظهرت النتائج أن قيم عمق الماء الأرضي النسبي يتناسب عكسيا مع معاملات مسافات الصرف وأن أعلي القيم

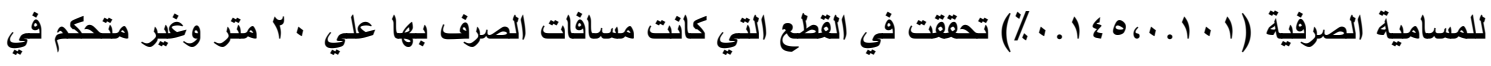

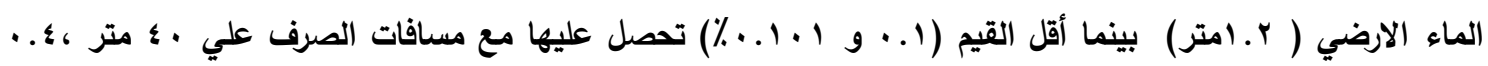

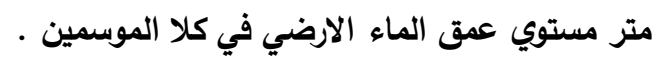

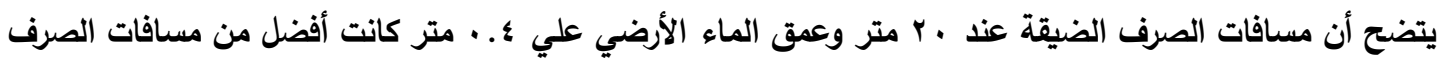
الواسعة علي مسافة •. متر في خفض ملوحة التربة ، نسبة الصوديوم المدمص، الكثافة الظاهرية بالمقارنة بالقيم المتحصل عليها قبل تنفيذ نظام الصرف. وان التحكم في الصرف يقلل من كميات المياه المنصرفه الي المصارف مقارنة بالصرف التقليدي كما أعطيت مسافات

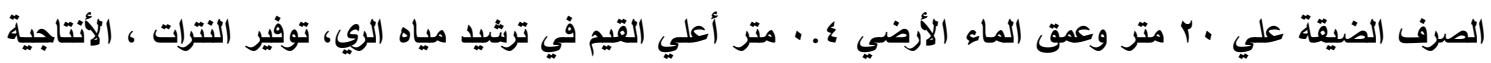

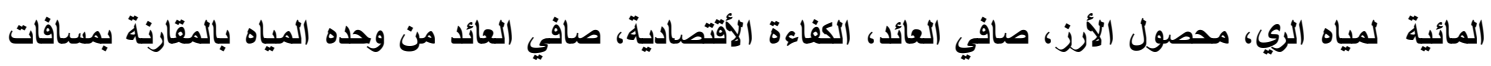

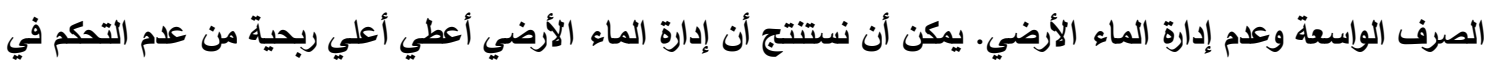

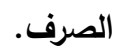




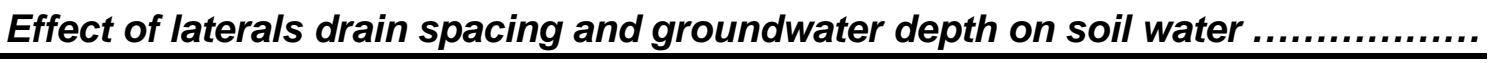

